\title{
The relationship between the postpartum uterine prolapse incidence and some macro minerals serum level deficiency in cow in Basra province
}

\author{
H. A. Khamees A. A. Alfars T.A. Fahad
}

Coll. of Vet. Med.- Univ. of Basra

\begin{abstract}
The study was performed to investigate macro minerals in the cow's serum suffering from post-parturient uterine prolapse compared with other cows without incidence of prolapse. In the present study, 30 cows during 72 hours after calving, 15 calving without uterine prolapse (control group), and 15 calving suffer from uterine prolapse (treated group).The results showed a drastic decrease in serum macro minerals levels of treated group animals, so the results show the calcium serum level $(5.56 \pm 0.19 \mathrm{mg} / \mathrm{dl})$, phosphorus $(3.30 \pm 0.30 \mathrm{mg} / \mathrm{dl})$ and magnesium $(1.42 \pm 0.09 \mathrm{mg} / \mathrm{dl})$ compared with levels in control animals that show $(10.34 \pm 0.44,5.33 \pm 0.21,3.79 \pm 0.37) \mathrm{mg} / \mathrm{dl}$ of the calcium, phosphorus and magnesium successively. It was concluded that deficiency of calcium, phosphorus and magnesium serum level in the last period of pregnancy and at the parturition might be possible causes of post parturient uterine prolapse in these cows.
\end{abstract}

Key words: postpartum, uterine prolapse, serum minerals, cow.

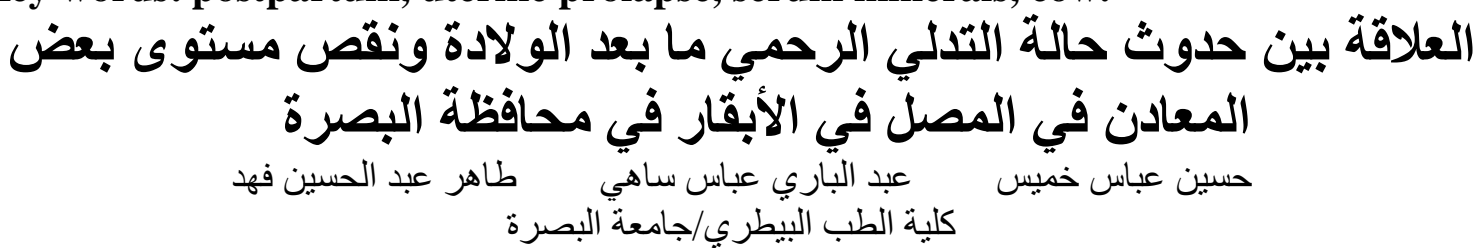

\section{الخلاصة}

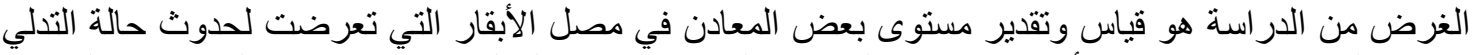

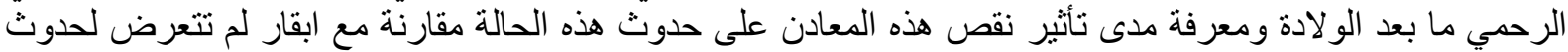

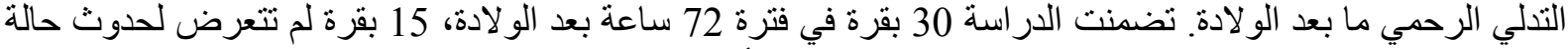

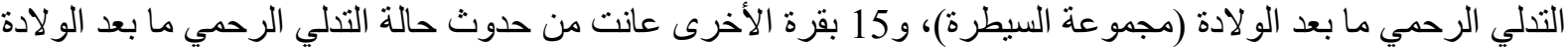

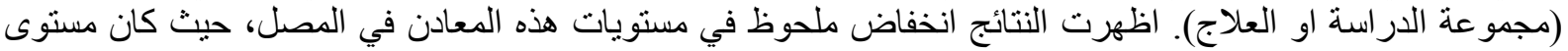

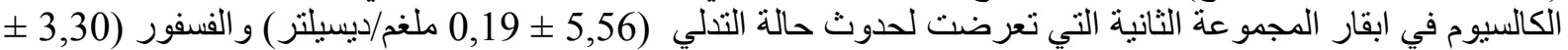

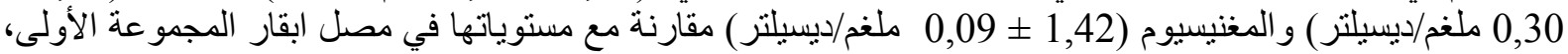
حيث كانت مستوياتها (10,34 =

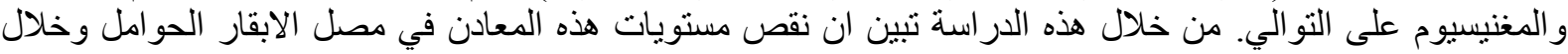

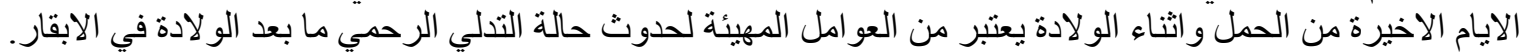

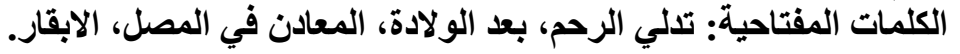

\section{Introduction}

Uterine prolapse is a common obstetrical problem, which adversely affects productive and reproductive performance of cattle by affecting postpartum return to estrus, conception rate and calving interval, and the incidence of uterine prolapse as $42.9 \%$ among various obstetrical problems in cattle [1]. Hypocalcaemia results in myometrial fatigue and delays cervical involution, both of which could predispose to uterine prolapse [2] and [3].Forced extraction of the fetus has also been incriminated as an etiological factor. Foods containing estrogenic substances, such as subterranean clover pasture in Western Australia, soybean meal, moldy maize and barley, may result in a high incidence of uterine prolapse [4]. Atony of the reproductive tract and weakness of genital organs may predispose the condition but it is less commonly seen in pastured or grazing cattle than the stall fed or zero grazing animals [5]. Uterine prolapse 
occurs within few hours after calving. The condition is invariably associated with hypocalcaemia, which results in lack of uterine tone and delayed cervical involution [6]. Prolapse or eversion of the uterus is also called casting of the "Calf bed". Pluriparous cows are more often involved than heifers [7]. However, there is little information in the literature on serum macro mineral levels in cows with uterine prolapse. Therefore, the present project was planned to investigate serum macro mineral contents in prolapsed animals and to compare them with nonprolapsed animals of the same species.

\section{Materials and methods}

The present study was conducted on cows brought to the private veterinary clinics in Basra province. For this purpose, a total of 30 calving cows were selected, out of which 15 were suffering from uterine prolapse (treated) and 15 were without uterine prolapse (control), and both the two groups are in same period (72 hours after calving). About $10 \mathrm{ml}$ of blood was collected (without anticoagulant) from each animal aseptically in clean, sterilized syringe from jugular vein, the blood put in the sterilized test tube.
Serum was separated from blood by using the centrifuge at $300 \mathrm{p} / \mathrm{min}$ for five minutes, then the serum was draw back by the pipette to the new test tube, and stored at $-20^{\circ} \mathrm{C}$ until analyzed for the calcium, phosphorus and magnesium contents. Serum calcium concentrations were estimated using the calcium kit Cobas c III (Roche, Germany), serum phosphorus concentrations were estimated using the phosphorus kit Cobas c III (Roche, Germany), and also Serum magnesium concentrations were estimated using the magnesium kit Cobas c III (Roche, Germany). These tests for calcium, phosphorus and magnesium are done by

Reagent Assay, using the Cobas c 111 system [8].

\section{Statistical analysis}

The mean $( \pm$ SE) values of calcium, phosphorus and magnesium of different experimental groups of cows in the two groups. The values were considered significant at $\mathrm{P}<0.0001$.Using computer program (SPSS 14). So the results show existence moral differences between the two groups, show table (1).

Table 1 Mean values $( \pm \mathrm{SE})$ of macro-minerals $(\mathrm{mg} / \mathrm{dl})$ in treated and control group cows

\begin{tabular}{|c|c|c|c|}
\hline Animals groups & \multicolumn{2}{|c|}{ parameters } \\
\cline { 2 - 4 } & $\begin{array}{c}\text { Calcium serum } \\
\text { Level }\end{array}$ & $\begin{array}{c}\text { Phosphorus serum } \\
\text { Level }\end{array}$ & $\begin{array}{c}\text { Magnesium serum } \\
\text { Level }\end{array}$ \\
\hline $\begin{array}{c}\text { Treated group } \\
\text { (cow with uterine prolapse) }\end{array}$ & $5.56 \pm 0.19 *$ & $3.30 \pm 0.30$ & $1.42 \pm 0.09$ \\
\hline $\begin{array}{c}\text { Control group } \\
\text { (cows without uterine prolapse) }\end{array}$ & $10.34 \pm 0.44$ & $5.33 \pm 0.21$ & $3.79 \pm 0.37$ \\
\hline
\end{tabular}

$*(\mathrm{P}<0.0001)$. Each value is based on 15 samples $(\mathrm{n}=15)$.

\section{Results}

Mean serum values $( \pm$ SE) for calcium, phosphorus and magnesium in control and uterine prolapse affected cows are presented in Table 1. In treated group, mean serum calcium concentration in cows suffering from uterine prolapse was $5.56 \pm 0.19 \mathrm{mg} / \mathrm{dl}$, while in control cows it was $10.34 \pm 0.44$ $\mathrm{mg} / \mathrm{dl}$. In both groups, mean serum calcium concentration was significantly lower $(\mathrm{P}<0.0001)$ in cows suffering with uterine prolapse compared with that of cows without uterine prolapse. Mean serum values $( \pm \mathrm{SE})$ phosphorus concentration in the serum of cows suffering with uterine prolapse was $3.30 \pm 0.30 \mathrm{mg} / \mathrm{dl}$, versus $5.33 \pm 0.21 \mathrm{mg} / \mathrm{dl}$ in control cows. Serum phosphorus concentration differed significantly $(\mathrm{P}<0.0001)$ in treated animals in comparison with control cows. Mean magnesium concentration in the serum of cows suffering with uterine prolapse was $1.42 \pm 0.09 \mathrm{mg} / \mathrm{dl}$, while in control cows it was $3.79 \pm 0.37$ $\mathrm{mg} / \mathrm{dl}$. In both groups, magnesium concentration in affected or treated cows was significantly higher $(\mathrm{P}<0.0001)$ compared with the control cows. It was revealed that serum calcium; phosphorus and magnesium 
levels in the serum in cows of two groups were different, however reached significance in case of calcium, phosphorus and magnesium.

\section{Discussion}

In the present study, the mean serum calcium concentration in the cows suffering with uterine prolapse was significantly lower compared to cows without uterine prolapse. Similarly [9] and [10] reported lower calcium concentrations in cows suffering from uterine prolapse. The mean serum calcium concentration recorded in control cows was higher than those reported by [11], while it was lower than those reported by [12] and [13] for cows. These differences may be due to difference in geographical areas because the blood mineral contents in cows have been reported to differ from area to area [14]. In the present study, the mean phosphorus concentration in the serum of cows suffering with uterine prolapse was significantly lower compared to cows without uterine prolapse. These results corroborate with those reported by [15]). However, [16] reported nonsignificantly lower phosphorus concentration in cows suffering with uterine prolapse compared with that of cows without uterine prolapse. The mean serum phosphorus concentration in control cows was similar to that reported by [14], while higher values were reported by [13] and [17]. In the present study, the mean serum phosphorus concentration in cows of control group was lower than that reported by [6] and [14]. This may be due to different areas in which research was conducted as blood mineral contents in animals vary from area to area. The mean serum magnesium concentration in cows suffering with uterine prolapse was significantly higher compared with cows without uterine prolapse. Similar results have been reported by [18], while non-significant

\section{References}

1-Goff J. P; Kehrli M. E.; and Horst R. L., (1990). The pathology and prevention of milk fever in cows. J. Dairy Sci., 73: 1182.

2-Murphy A. M. and Dobson H. (2002): Predisposition, subsequent fertility and mortality of cows with uterine prolapse Vet. Rec. 151, P.p. 733-735.

3-Roberts S. J. (2004): Injuries and diseases of the puerperal period. In: Veterinary Obstetrics and differences in magnesium concentration between prolapse affected and healthy cows were reported by [14] and [18] for cows.[9] Reported significantly lower serum magnesium concentration in cows suffering with uterine prolapse. The mean serum magnesium concentration in control cows was higher than that reported by [19], while lower values were reported by [6]. Among micro minerals, serum copper and zinc were lower in prolapsed cows compared to healthy animals [20].Calcium is necessary for neuromuscular excitability, cell membrane permeability, muscle contraction and nerve impulse transmission and its deficiency can lead to reduced vaginal and uterine muscle tone which predisposes the animals to vaginal and uterine prolapse [17]. A negative correlation between the serum calcium, phosphorus and estrogen levels has been documented [21]. The increased level of estrogen during earlier part of third trimester of pregnancy may result in greater relaxation of pelvic structure and the situation is further accentuated by decreased levels of calcium, resulting in atony of the reproductive tract, thereby disposing the animal to vaginal prolapse, it is possible that a combination of these two factors may initiate the vaginal and uterine prolapse. It has earlier been reported that mineral contents of plants vary with the soil chemical composition and is affected by the climatic influences like temperature, rain fall and water drainage in a given area [22]. A study to develop a correlation between the soil, fodder and serum mineral contents may be more revealing. Based on the information obtained from this study, it appears that deficiency of calcium, phosphorus and magnesium during pregnancy might be the possible causes that predispose cows to postpartum uterine prolapse.

Genital Diseases (Theriogenology). $2^{\text {nd }}$ ed. [Indian reprint]. CBS Publishers and Distributors, New Delhi, India, Pp 300-335.

4-Marques L. C.; Marques J. A.; Peiro J. R., Oliveira J. A. and Mendes L. C. (1996). Serum calcium, phosphorus and magnesium levels in cows with cervicovaginal or uterine prolapse. ArquivoBrasileiro-de-Medicina-Veterinaria-e-Zootecnia, 48(2): 165-173.

5-Noakes E. D.; Parkinson T. J. and England G.C. (2001): Post parturient prolapse of the uterus, 
chapter19. In: Arthur's Veterinary Reproduction and Obstetrics. 8th Ed. Harcourt (India) Pvt. Ltd., New Delhi, pp. 333-338.

6-Pathak, M. M. and Janakiraman K. (1987): Blood serum calcium, inorganic phosphorus and magnesium at different stages of pregnancy in Surti buffaloes. Indian J. Anim. Sci., 57: 398-402.

7-Risco, C. A.; Reynokls J. P. and Hird D., (1984): Uterine prolapse and hypocalcaemia in dairy cows. J. Amer. Vet. Med. Assoc., 185(12): 1517-1519.

8-Anonymous (2007): Cobas Integra and life Needs Answers are trademarks of Roche. Roche Diagnostics. All rights reserved. 317-39034 -1207.

9-Freed R. J., (1987). M-STAT C. Michigan State Univ., Michigan, USA.

10-Pravesh K. (2011): Post-Partum uterine prolapse in a non-descriptive cow. Department of Veterinary Gynaecology and Obstetrics, College of Veterinary and Animal. Sciences, Cskhpkv, Palampur. P.p. 162- 172.

11-Roberts S. J. (1998): Vaginocervical prolapse In: Veterinary Obstetrics and Genital Diseases (Theriogenology). $2^{\text {nd }}$ ed. [Indian reprint] CBS Publishers and Distributors, New Delhi, India, pp. 198-196.

12-Salmanoglu, R. and Salmanoglu B., (1998): Blood calcium concentrations and clinical observations in puerperal hypocalcaemic cows. Vet. Fakul. Dergisi, Ankara Univ., 45(1): 151-157.

13-Das p.; Biswas S.; Ghosh T.K. and Halder S. (2002): Micronutrient status of dairy cattle in new alluavial zone of West Bengal. India J. Amin. Sci. 72 (2), 171-173.

14-Jagatheesan P.; Selvaraju M.; Ramesh V. Kumar S. and Chandrahasan C. (2005): Effect of advanced pregnancy and early lactation on blood biochemical constituents in Murrah buffaloes. India Vet. J., 82 (4): 401-403.

15-Nanda A. and Sharma R. (1982): Incidence and etiology of prepartum prplapse of vagina in buffaloes. India J. Dairy Sci., 35 (2): 168-171.

16-Kumar R.; Sharma I,; Rao V. and Quadri M. (2001):Status of haemogram, plasma proteins, minerals and electrolytes during pregnancy, a noroxia and sub-clinical ketosis in cows and buffaloes. India J. Amin. Sci., 712 (2): 118-121.

17-Roberts S. J. (1986): Veterinary Obstetrics and Genital Diseases. $3^{\text {rd }}$ Ed., Edward Brothers, Microghan, USA. 233-240.

18-Vicenti L.; Gula M.; Carazzone W.; Fortina R. and Quaranta G. (1992): Serum profile of estradiol $17 \beta$, progesterone and some electrolytes in pregnant cows of the piomontes breed with vaginal prolapse. Atti della Societa Italiana di Buiatria, 24: 559-564.

19-Steel R.; Torrie H. and Dickey A. (2006): Principles and procedures of statistics. A biometrical approach. $3^{\text {rd }}$ Ed., McGraw Hill Co. New York, USA.

20-Seitaridis K. and Papadopoulos E. (1978): Contributions to the aetiology of uterine prolapse in prignant cows. Vet. Bull., 48: 5058.

21-Pandit R.; Gupta K. and Raman P. (1982): A clinical study on prolapse of vagina and uterus in buffaloes. India Vet. J., 59: 975-980.

22-Mcdowell L. and Arthington D. (2005): Minerals for Grazing Ruminants in Tropical Regions. Extension Bulletin, Anim. Sci. Dept., Univ.Florida, USA. 